\title{
EFFECT OF NATURAL AND SOLAR ENERGY DRYING SYSTEMS ON DRYING CHARACTERISTICS OF MARIGOLD MEDICAL PLANT
}

Abdel Ghaffar, E. A. ${ }^{* * *}$, Shokr, A. Z. ${ }^{* * *}$, Rashwan, M. A ${ }^{* *}$, Shaaban, E. S.

\section{ABSTRACT}

Two drying systems, natural sun and solar energy systems (active and passive) were used in this research to determine the effect of drying systems on drying characteristics of marigold medical plant.

The natural sun drying system gave the worst average drying rate of $0.29 \%$ (db/min) due to long drying period of $39 \mathrm{~h}$ and low levels of drying temperature of $23.1{ }^{\circ} \mathrm{C}$.

The solar energy systems consist of two drying systems, passive and active solar drying systems.

In the passive solar drying system (tunnels), the highest average drying properties were in tunnel 4 which had average tunnel temperature of $41.2{ }^{\circ} \mathrm{C}$, the average drying rate was $0.64 \%(\mathrm{db} / \mathrm{min})$ and the total accumulated drying time was $16 \mathrm{~h}$.

In the active solar drying system, the time required for drying the marigold petals and its drying rate ranged from 29 to $31 \mathrm{~h}$ and 0.33 to $0.39 \%$ (db/min) respectively. The active solar drying system increased the drying rate comparing with the natural sun drying system.

\section{INTRODUCTION}

7 he medicinal plants in Egypt have an important export value, in spite of their small growing area, which is less than $1 \%$ of the total agricultural area. In 1987, the export value of medicinal plant export was 15 million L.E., which represented $2.9 \%$ of the total agricultural export value (514.3 million L.E). They are considered as a natural alternative to the chemical drugs because of their medical side effects. The total agricultural area of marigold in Egypt was $160 \mathrm{Fed}$ in 1984 and the total production was 896 ton. Meanwhile, in 1994 the total agricultural area of marigold in Egypt was 279 Fed and the total production was 2357 ton. (Agricultural Statistics, 1984 and 1994)

\footnotetext{
${ }^{* * * *}$ Prof. Agric. Eng. Dept., Fac. of Agric. (Chatby), Alex. Univ., Alex.

** Assist. Prof. Agric. Eng. Dept., Fac. of Agric. (Chatby), Alex. Univ., Alex.

"Eng. - M. Sc. Agric. Eng. Dept., Fac. of Agric. (Chatby), Alex. Univ., Alex.
} 
Bogers et al. (2006) have made investigations on Salvia officinal's. They found that the optimal drying temperature was $50^{\circ} \mathrm{C}$, and quality reduction due to discoloration occurred at higher temperatures. Also they found that drying at $45^{\circ} \mathrm{C}$, reduced drying time by $60 \%$ and reduced energy consumption by $35 \%$. However, comparisons of different species revealed that no general recommendations can be made, but that each species has to be investigated individually.

Mohamed et al. (2004) have used the convective solar drying experiments in thin layers of Citrus aurantium leaves. An indirect forced convection solar dryer consisting of a solar air collector, an auxiliary heater, a circulation fan and a drying cabinet is used for the experiments. The air temperature was varied from 50 to $60{ }^{\circ} \mathrm{C}$; the relative humidity from $41 \%$ to $53 \%$; and the drying air flow rate from 0.0277 to $0.0833 \mathrm{~m}^{3} / \mathrm{s}$.

When medicinal plant materials are prepared for use in dry form, the moisture content of the material should be kept as low as possible in order to reduce damage from mould and other microbial infestation (Heber Youngken, 2003).

Hall and pear (1980) stated that drying farm crops are important from the following standpoint: (1) early harvest minimizes field damage and shatters loss and facilitates tillage operations for such products as corn, small grains and grass seeds. (2) Long period storage without product deterioration is possible. (3) Permits the farmer to sell better quality products which worth more to him and to those whop must use those products. (4) Products with greatest economic value are produced, for example tobacco, dried fruits, and vegetables. (5) Waste products can be converted to useful products.

Shokr (1986) designed a laboratory dryer and fabricated for rough rice thin-layer drying studies. The experimental data were used to develop a new mathematical model to predict the moisture content as a function of time, grain initial moisture content, air temperature and relative humidity. The correlation coefficient between predicted and experimental moisture content for the different drying conditions was found to be $95 \%$. 
Muller (1992) determined the drying factor for mint, balm, chamomile and salvia. He found that the drying factor was 13.5, 22.5, 27.5, 12.6 $\mathrm{gm} / \mathrm{kg} \mathrm{h}$ for mint, balm, chamomile and salvia respectively.

Akradalieve (1980) stated that the products at temperature above $70^{\circ} \mathrm{C}$ have a strong caramelized-sugar taste. This implies that increase of drying temperature above $70^{\circ} \mathrm{C}$ in the drying process is inadvisable.

Megahed (1980) studied the effect of drying method of dill herb on moisture and volatile oil. He noted that the losses in the volatile oil during drying in general, when compared with the oil content of the fresh. In the sunlight drying the losses could be expected to be more. The moisture content before and after drying was 84.2 in the fresh herbs reduced to $9.4 \%$ in the dried dill.

Bezner et al. (1987) dried medicinal plants by stabilizing them in the freshly harvested state (or, if frozen products are used, during or immediately upon thawing), and drying them in presence of suitable carrier under mild conditions. As carriers, salts (electrolytes), proteins, carbohydrates, or mixtures of it can be used.

Buser et al. (1999) studied the effect of drying temperature and airflow rates on the detachment marigold petals. They reported that the pigment content degrade at higher drying temperature.

\section{MATERIALS AND METHODS}

Fresh samples of marigold medicinal plant (Calendula officinal's), are used as flowers or medical industrials. The samples were planted on faculty of Agricultural Farm, Alexandria University -Winter season. The starting of cutting flowers was begun weekly through March, April and the first two weeks of May.

\section{A- The natural sun-drying system:}

After petalling of marigold flowers, the samples were spread in thin layer at circular trays (20-cm diameter) and placed in well-ventilated place in full sun for one day then continued drying at shaded place. At night, the trays were taken indoors. The sample weights were measured hourly.

\section{B- The solar-energy drying systems:}

Two different types of solar energy drying system represented both the passive and active solar drying systems. The experiments were run for solar drying marigold petals and replicated four times per treatment. The 
experiments made on the two solar systems until the uniformity of moisture content was achieved.

\section{The passive solar-drying system:}

In this drying system, a tunnel $(2 \times 1 \times 0.5 \mathrm{~m})$ was installed with a plastic cover sheet as shown in Fig. (1). It has two ventilation openings. The front down and the rear later top one to insure flowing of a natural air through tunnel dryer. The tunnel's door was opened and closed and a black body sheet was added under the samples or below the plastic cover to form the required treatments.

1- The front down ventilation opening

2- The later top ventilation opening

3- Tunnel's door

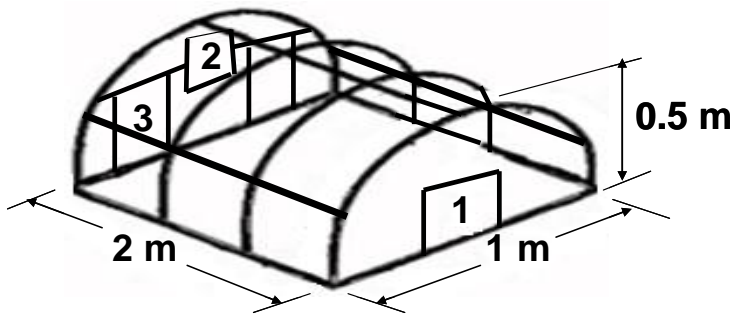

Fig. (1): Passive solar drying system (tunnel dryer).

\section{The active solar-drying system:}

This system consisted of a $2 \times 1 \mathrm{~m}$ flat - plate solar collector as illustrated in Fig. (2). A flat galvanized sheet metal was installed and fixed inside the wooden frame. The plate-absorbing surface was painted black to increase the collector thermal-efficiency. A glass sheet, $6 \mathrm{~mm}$ thick, was placed on the top of the wooden frame at a distance of $12 \mathrm{~cm}$ from the absorbing plate to form air stream pass and made of wood and placed under the absorbing plate. The moving air stream picked up heat from the upper side of the absorbing surface.

The collector was connected to $0.8 \times 0.7 \times 0.3 \mathrm{~m}$. metal thin layer dryer containing six circular trays $(20 \mathrm{~cm}$ in diameter/tray). They mounted at the top with a hopper shaped bottom through $50 \mathrm{~cm}$ pipe long $(15 \mathrm{~cm}$. in diameter). Only four of the six trays were used in drying experiments. Numbers of baffles were placed at the bottom of the box to regulate and insure uniformity of air velocity through the four trays. A $2.7 \mathrm{hp}$. Centrifugal fan was connected to the flat plate air solar collector through 
$2 \mathrm{~m}$ pipe $(15 \mathrm{~cm}$. in diameter). The airflow rates were controlled by a gate mounted on the fan exit.

The solar air collector was oriented toward the south to maximize the solar energy efficiency. The tilt angle of solar air collector was $30^{\circ}$ from horizontal plane.

\section{C- Instrumentation}

\section{Air flow rate measurements:}

A turbo meter wind speed indicator was used to measure the air velocity and to estimate different levels of air flow rate.

In solar air collector, the velocity indicator measured the velocity in different levels of the out let pipe section concentrated with the solar collector to calculate its solar collector air flow rates (Qc). The apparatus also was used to measure air velocity at the four trays dryer bed to calculate their airflow rate $(\mathrm{Qb})$. The active solar drying bed airflow rates were equal to their summation with equal to the solar collector airflow rate $(\mathrm{Qc})$ as shown in the following formula:

$$
\mathrm{Qb}=\mathrm{Qc} / 4
$$

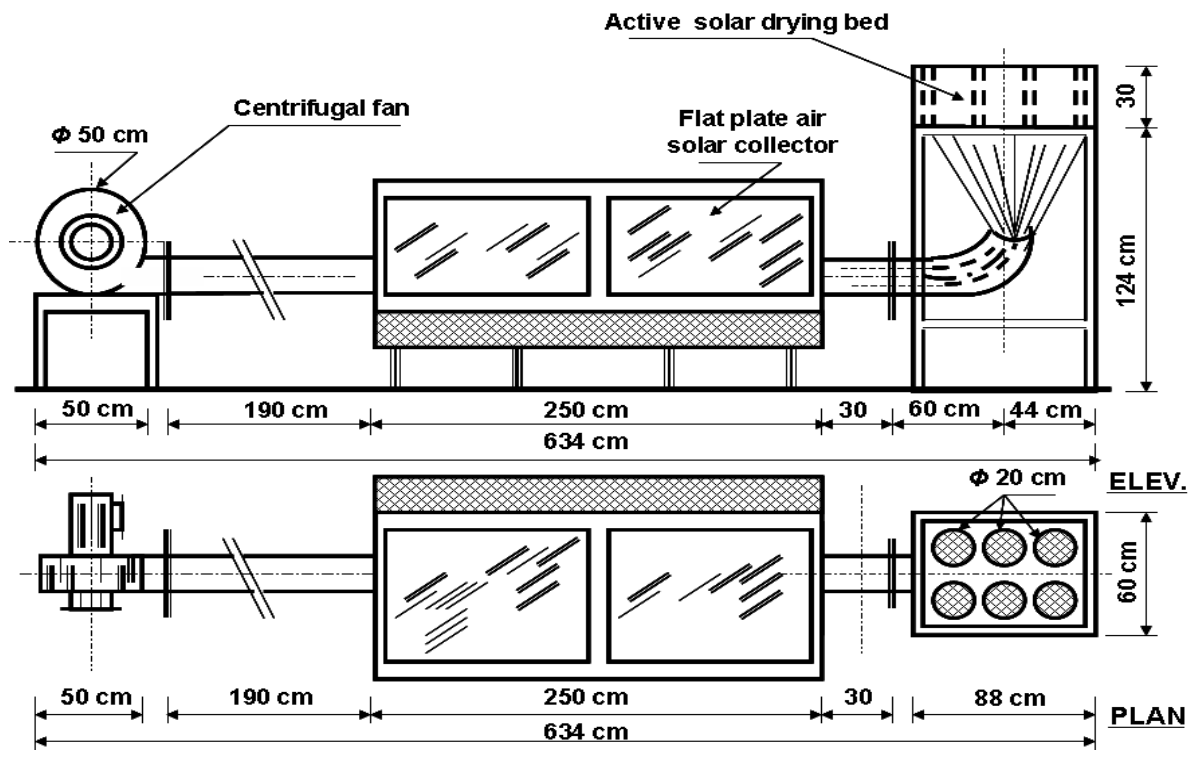

Fig. (2): Active solar drying system. 


\section{Temperature measurements:}

For tunnel dryer, three positions of thermocouples were fixed at the bottom, the middle and upper to measure and calculate the average air tunnel temperature.

The active solar air collector drying system was fitted also with copperconstantan thermocouples fixed at the inlet and the outlet of air solar air collector. Another four fittings of thermocouples were fixed at the outlet of the four solar drying beds.

The ambient air temperature was measured by positioning three thermocouple points in a wall-ventilated shaded place. All temperature data were measured through thermocouple thermometer digital sensors which were connected to a manual selective switch distributor which connected with ten thermocouples cables.

The wet bulb ambient air temperatures were measured by using the ordinary thermo-glass thermometers with a wetted weft around the bulb. An air stream was blown through the wetted weft. This would help to estimate the relative humidity of both ambient and drying air.

\section{Moisture content measurements:}

A $0.1 \mathrm{~g}$ balance accuracy was used to determine the moisture content for all samples by recording the sample weight for marigold petals. The moisture content was calculated in wet basis and dry basis.

The initial sample weight for all experiment was $60 \mathrm{~g}$. The initial moisture content was calculated by utilizing the oven method at $105^{\circ} \mathrm{C}$. for $24 \mathrm{~h}$. (Buser, 1999).

\section{D- Experimental design:}

The solar energy drying systems were divided into two methods; active and passive solar drying systems replicated four times per treatment. The passive solar drying system was described for running experiments as tunnel dryer. In the first treatment; natural air was passed through the samples within the bottom and upper air tunnel openings to make natural air convection. The tunnel's door in this treatment was opened to maximize the air flow rate. This treatment was named tunnel 1. In the second treatment (tunnel 2), there was a natural convection, but tunnel's door was closed to accumulate maximum solar energy, and a black body was put below the samples to increase the required heat for drying 
marigold petals. In the third treatment (tunnel 3), the black body was put below the plastic sheet. In the fourth treatment (tunnel 4), tunnel's door was closed.

For active solar drying system, three treatments with 4 replicates were studied at three levels of airflow rates; 2.7, 3.6 and $5 \mathrm{cu}-\mathrm{m} / \mathrm{min}$., divided through the dryer apparatus into four equivalent airflow rates in each treatment $0.675,0.90$ and $1.25 \mathrm{cu}-\mathrm{m} / \mathrm{min}$.

In the natural sun drying method, marigold petals were exposed to direct sun rays for one day, and then moved to a well conditioned place to continue the drying process. This treatment was replicated four times daily from 8:00 AM to 4:00 PM until the test end.

\section{RESULTS AND DISCUSSION}

\section{A. Natural sun drying system of marigold petals}

The averages of natural sun-drying characteristics were collected in these experiments and the period of experiment was run in five days of April month, the initial moisture content (IMC) was 663.36\%, dry basis (db) and the equilibrium moisture content EMC, db was $11.98 \%$ with an average relative humidity of ambient air $\mathrm{RH}, 65.0 \%$. The total drying rate (TDR) was $0.29 \% \mathrm{db} / \mathrm{min}$. and the total drying time to ensure three values of equilibrium moisture content was $39 \mathrm{~h}$. and equilibrium moisture content time (EMCT) was $37 \mathrm{~h}$. The average air temperature for natural sun drying experiment was $23.1^{\circ} \mathrm{C}$. The natural sun drying system had the worst drying results because of both the lower ambient air temperature and the lower average drying rate of marigold petals.

Moisture content dry basis MC (db) curve is shown in Fig. (3), which illustrate decreasing of moisture content with accumulated drying time. To express the relationship between the moisture content dry basis, MC (db) \% versus accumulated drying time, ( $\mathrm{t}$ ), $\mathrm{h}$, data of the experiments were analyzed to obtain an empirical equation by the method of best fit. It was found that using polynomial equation was the best equation, which had good $\mathrm{R}^{2}$ value.

\section{B. Solar energy drying system of marigold petals:}

\section{The passive solar drying system of marigold petals:}

Table (1) illustrates the average characteristics of passive solar drying of marigold petals. The initial moisture contents of the marigold petals 
ranged between $545.16 \% \mathrm{db}$ and $663.36 \% \mathrm{db}$ while the equilibrium moisture content ranged between $9.69 \% \mathrm{db}$ and $10.77 \% \mathrm{db}$. The maximum average relative humidity of ambient air $\left(\mathrm{RH}_{\mathrm{av}}\right)$ was $64.7 \%$ at tunnel 2 and the minimum average relative humidity of ambient air $\left(\mathrm{RH}_{\mathrm{av}}\right)$ was $52.9 \%$ at tunnel 1 .

The lowest average tunnel temperature $\left(\mathrm{Tt}_{\mathrm{av}}\right)$ was $32.0^{\circ} \mathrm{C}$ in tunnel 1 because tunnel's door was opened that leaded up to a minimum average drying rate (ADR) which had a value of $0.38 \% \mathrm{db} / \mathrm{min}$.

The maximum total accumulated drying time (TADT) had a value of 31 $\mathrm{h}$. The highest average temperature $\left(\mathrm{Tt}_{\mathrm{av}}\right)$ in tunnel 4 was $41.2^{\circ} \mathrm{C}$ due to closed tunnel's door which worked as accumulated solar radiation.

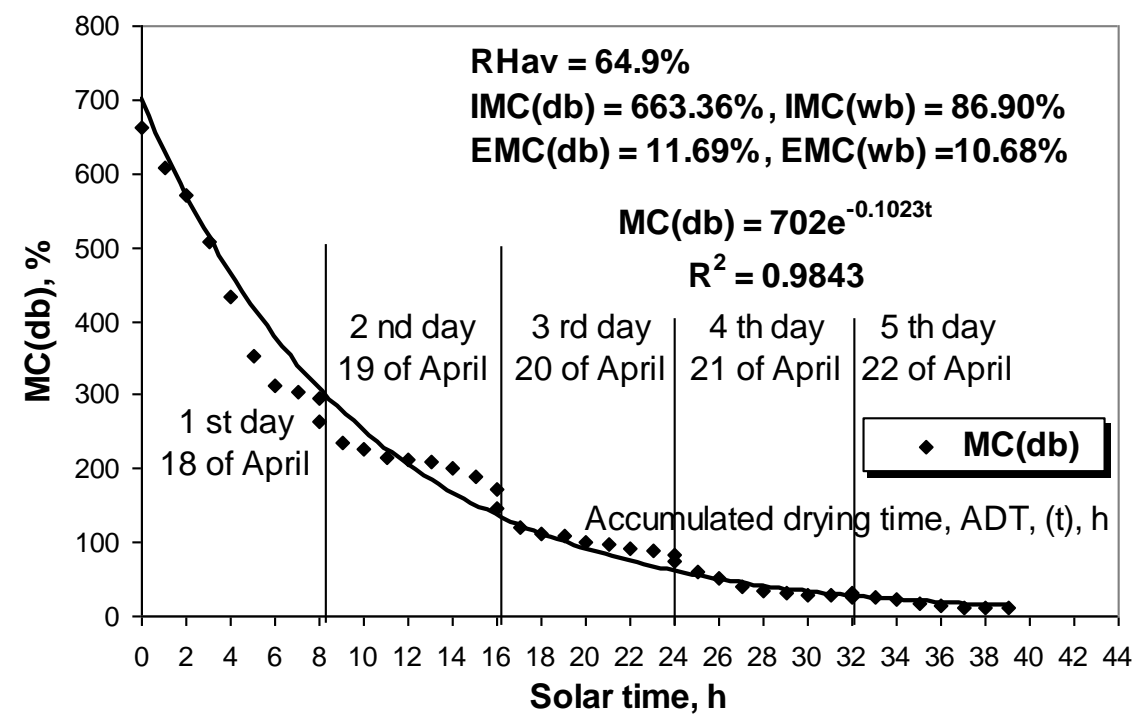

Fig. (3): Moisture content dry basis, $\mathrm{MC}(\mathrm{db}), \%$ versus accumulated drying time $(\mathrm{t}), \mathrm{h}$ and solar time at natural sun drying system of marigold petals.

Consequently, it maximized the average drying rate (ADR) which had value of $0.64 \% \mathrm{db} / \mathrm{min}$ and it minimized the total accumulated drying time (TADT) which had value of $16 \mathrm{~h}$. Tunnel 2 and tunnel 3 results were approximately the same. Average ambient air temperature $\left(\mathrm{Ta}_{\mathrm{av}}\right)$ ranged between $22.6^{\circ} \mathrm{C}$ and $26.1^{\circ} \mathrm{C}$. 
Table (1): characteristics of marigold petals with passive solar drying system.

\begin{tabular}{|c|c|c|c|c|c|c|c|c|c|}
\hline No & $\begin{array}{c}\text { Treatment of } \\
\text { the passive } \\
\text { solar drying } \\
\text { system } \\
\end{array}$ & $\begin{array}{c}\text { IMC } \\
\text { (db) } \\
\%\end{array}$ & $\begin{array}{c}\text { EMC } \\
\text { (db) } \\
\%\end{array}$ & $\begin{array}{l}\text { TADT } \\
\text { t, } \\
\text { (h) }\end{array}$ & $\begin{array}{c}\text { EMCT } \\
\text { (h) }\end{array}$ & $\begin{array}{c}\mathbf{T a}_{\mathrm{av}} \\
{ }^{\circ} \mathbf{C}\end{array}$ & $\begin{array}{c}\mathbf{T t}_{\mathrm{av}} \\
{ }^{\circ} \mathrm{C}\end{array}$ & $\begin{array}{c}\text { ADR } \\
\%(\mathbf{d b}) / \\
\text { min }\end{array}$ & $\begin{array}{c}\mathbf{R H}_{\mathrm{av}} \\
(\%)\end{array}$ \\
\hline $\mathrm{a}$ & Tunnel 1 & 663.36 & 09.69 & 31 & 29 & 26.1 & 32.0 & 0.38 & 52.9 \\
\hline $\mathrm{b}$ & Tunnel 2 & 655.86 & 10.77 & 22 & 20 & 22.6 & 38.1 & 0.54 & 64.7 \\
\hline $\mathrm{c}$ & Tunnel 3 & 663.36 & 10.68 & 24 & 22 & 24.1 & 37.8 & 0.49 & 59.8 \\
\hline $\mathrm{d}$ & Tunnel 4 & 545.16 & 10.29 & 16 & 14 & 24.3 & 41.2 & 0.64 & 62.9 \\
\hline
\end{tabular}

For marigold petals in tunnel 4, the experiments were run from 29 to 30 of April. The initial moisture content (IMC) was $545.16 \%$, db. The moisture data were recorded hourly until the equilibrium moisture content (EMC) was achieved at value of $10.29 \%$, db.

Figure (4) shows the moisture content ( $\mathrm{MC} \%, \mathrm{db})$ were plotted and analyzed versus accumulated drying time (ADT), h, through two solar day experiments for marigold petals in tunnel 4 to obtain an empirical equation by using the best fit method. The experiments were finished after $16 \mathrm{~h}$ only because of the relative high tunnel air temperature (Tt), ${ }^{\circ} \mathrm{C}$. The ambient air temperature $(\mathrm{Ta}),{ }^{\circ} \mathrm{C}$ through two solar days experiment and tunnel average temperature $(\mathrm{Tt}),{ }^{\circ} \mathrm{C}$ were plotted against accumulated drying time in Fig. (5). The maximum tunnel air temperature (Tt) ranged between 49.4 and $50.5{ }^{\circ} \mathrm{C}$ at solar noon time through the experiment.

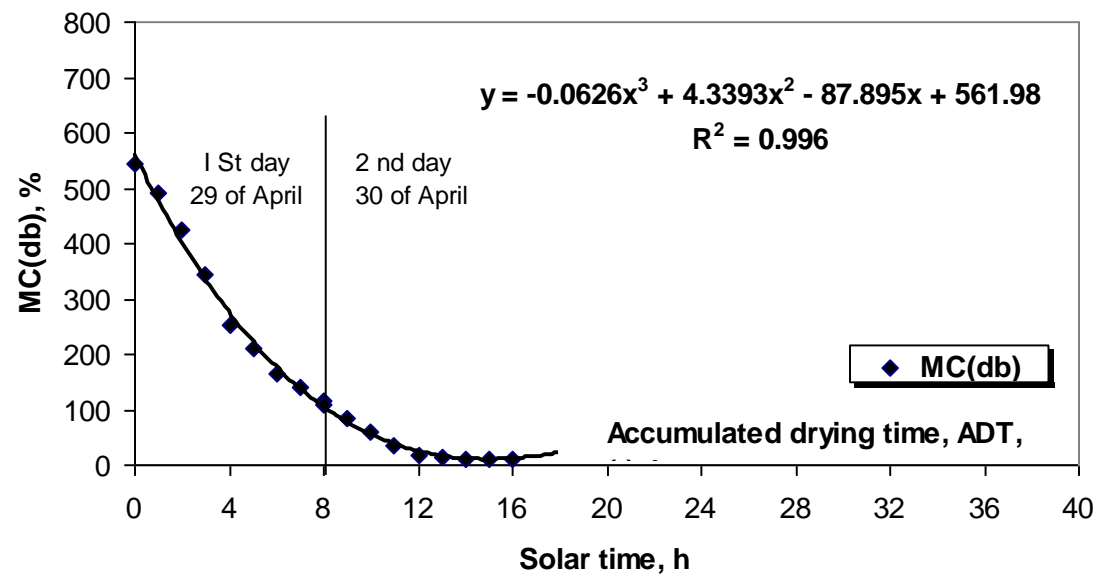

Fig. (4): Moisture content dry basis, MC (db), \%, versus accumulated drying time $(\mathrm{t}), \mathrm{h}$ and solar time at passive solar drying system for marigold petals in tunnel 4 treatment. 


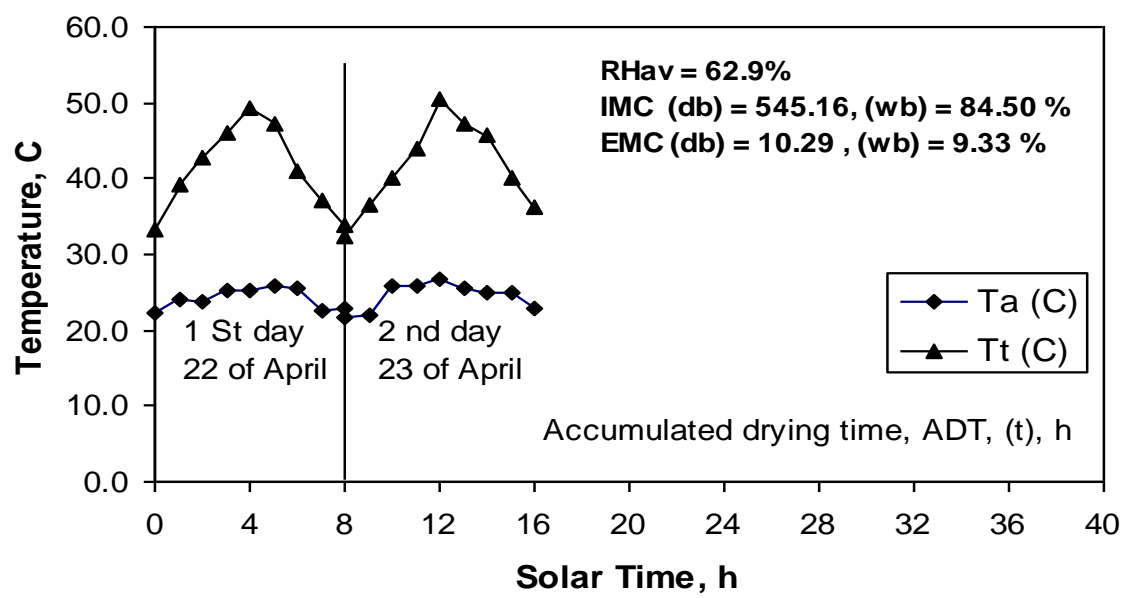

Fig. (5): Ambient air temperature (Ta), ${ }^{\circ} \mathrm{C}$ and tunnel air temperature $(\mathrm{Tt}),{ }^{\circ} \mathrm{C}$ versus accumulated drying time $(\mathrm{t}), \mathrm{h}$ and solar time with passive solar drying system through tunnel 4 treatment.

\section{The active solar-drying system of marigold petals:}

An air solar collector was used to heat a forced air to dry marigold petals. Three levels of airflow rate (Qc) passed through the used solar collector were $2.7,3.6$ and $5.0 \mathrm{cu}-\mathrm{m} / \mathrm{min}$. The designed solar heated air values passed through the four parts of drying bed $(\mathrm{Qb})$ were $0.675,0.900$ and $1.250 \mathrm{cu}-\mathrm{m} / \mathrm{min}$.

Table (2) represents the active solar drying characteristics for marigold petals through the three levels of the solar drying bed airflow rate $(\mathrm{Qb})$, (0.675, 0.900 and $1.250 \mathrm{cu}-\mathrm{m} / \mathrm{min})$. The initial moisture content (IMC), $\%$ ranged between $545.16 \%$, db and $663.36 \%$, db while the equilibrium moisture content (EMC), \% was ranged between $8.36 \%$, db and 10.68 $\%, \mathrm{db}$. The average relative humidity of ambient air was limited between $55.4 \%$ and $63.9 \%$. The maximum average ambient air temperature was $25.0{ }^{\circ} \mathrm{C}$ and the minimum average ambient air temperature was $24.1{ }^{\circ} \mathrm{C}$ during the time of running the experiments.

Table (2): characteristics of marigold petals with active solar drying system.

\begin{tabular}{|c|c|c|c|c|c|c|c|c|c|c|}
\hline No & $\begin{array}{l}\text { Treatment of the } \\
\text { active solar drying } \\
\text { system }\end{array}$ & $\begin{array}{c}\text { IMC } \\
\text { (db) } \\
\%\end{array}$ & $\begin{array}{c}\text { EMC } \\
(\text { db) } \\
\%\end{array}$ & $\begin{array}{l}\text { TADT } \\
\text { t, } \\
\text { (h) }\end{array}$ & $\begin{array}{c}\text { EMCT } \\
\text { (h) }\end{array}$ & $\underset{\mathrm{C}}{\mathbf{T a}_{\mathrm{av}}}$ & $\stackrel{\mathbf{T i}_{\mathrm{av}}}{\mathrm{C}}$ & $\begin{array}{l}\mathbf{I t}_{\mathrm{av}} \\
\mathbf{W} / \mathbf{m}^{2}\end{array}$ & $\underset{\%(\mathbf{d b}) / \min }{\operatorname{ADR}}$ & $\begin{array}{l}\mathbf{R H}_{\text {av }} \\
(\%)\end{array}$ \\
\hline $\mathrm{a}$ & $\mathrm{Qb}=0.675 \mathrm{cu}-\mathrm{m} / \mathrm{min}$ & 545.16 & 9.24 & 29 & 27 & 24.6 & 25.9 & 395.6 & 0.33 & 63.9 \\
\hline $\mathrm{b}$ & $\mathrm{Qb}=0.900 \mathrm{cu}-\mathrm{m} / \mathrm{min}$ & 633.68 & 8.36 & 31 & 29 & 25.0 & 26.3 & 348.2 & 0.36 & 55.4 \\
\hline $\mathrm{c}$ & $\mathrm{Qb}=1.250 \mathrm{cu}-\mathrm{m} / \mathrm{min}$ & 663.36 & 10.68 & 30 & 28 & 24.1 & 24.9 & 382.4 & 0.39 & 61.2 \\
\hline
\end{tabular}


Table (2) explained that there was decreasing relationship between the average outlet air solar collector temperature (To), ${ }^{\circ} \mathrm{C}$ and solar drying bed airflow rate $(\mathrm{Qb}), \mathrm{cu}-\mathrm{m} / \mathrm{min}$. The average drying rate (ADR), \% $\mathrm{db} / \mathrm{min}$, had no significant increasing when solar drying bed air flow rate $(\mathrm{Qb})$, cu- $\mathrm{m} / \mathrm{min}$ increased because in thin layer drying the effect of air flow rate on drying was not significant. The total accumulated drying time (TADT), h had approximately the same value ranged between $29 \mathrm{~h}$ and $31 \mathrm{~h}$ at all levels of active solar drying bed air flow rate $(\mathrm{Qb})$, cu$\mathrm{m} / \mathrm{min}$. that was due to the limited change of average drying rate (ADR), $\% \mathrm{db} / \mathrm{min}$, which ranged between 0.33 and $0.39 \% \mathrm{db} / \mathrm{min}$.

The experiment of the active solar drying system was run through 4 days from date 22 to 25 of April and starting with marigold petals initial moisture content of $663.36 \%, \mathrm{db}$. The equilibrium moisture content (EMC) was achieved after $28 \mathrm{~h}$ (1680 min) with final value of $10.68 \%$, db.

Figure (6) shows the moisture content (MC \%, db) was plotted and analyzed versus accumulated drying time (ADT), h to find out an empirical equation by using the best fit method. The outlet solar collector air temperatures (To), ${ }^{\circ} \mathrm{C}$ and the inlet solar collector air temperatures $(\mathrm{Ti}),{ }^{\circ} \mathrm{C}$ versus the accumulated drying time and solar time was shown in Fig. (7). The maximum outlet air temperature (To) ranged between 33.3 and $32.9{ }^{\circ} \mathrm{C}$ through the running experiment.

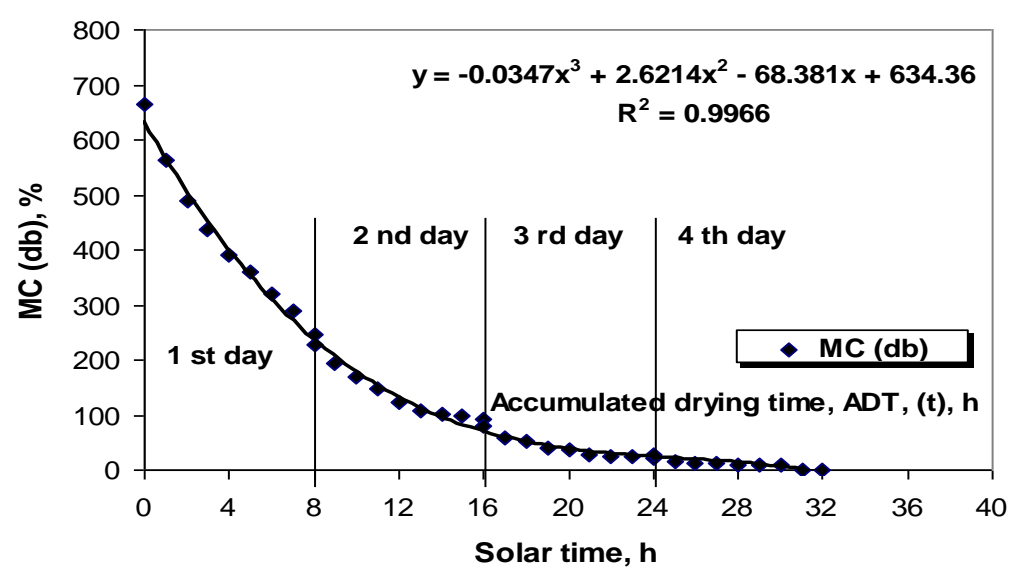

Fig. (6): Moisture content dry basis, MC (db), \%, versus accumulated drying time (t), $\mathrm{h}$ and solar time with active solar drying system for marigold petals through a solar air collector airflow rate $\mathrm{Qc}=5.0 \mathrm{cu}-\mathrm{m} / \mathrm{min}$ and active solar drying bed air flow rate $\mathrm{Qb}=1.250 \mathrm{cu}-\mathrm{m} / \mathrm{min}$. 


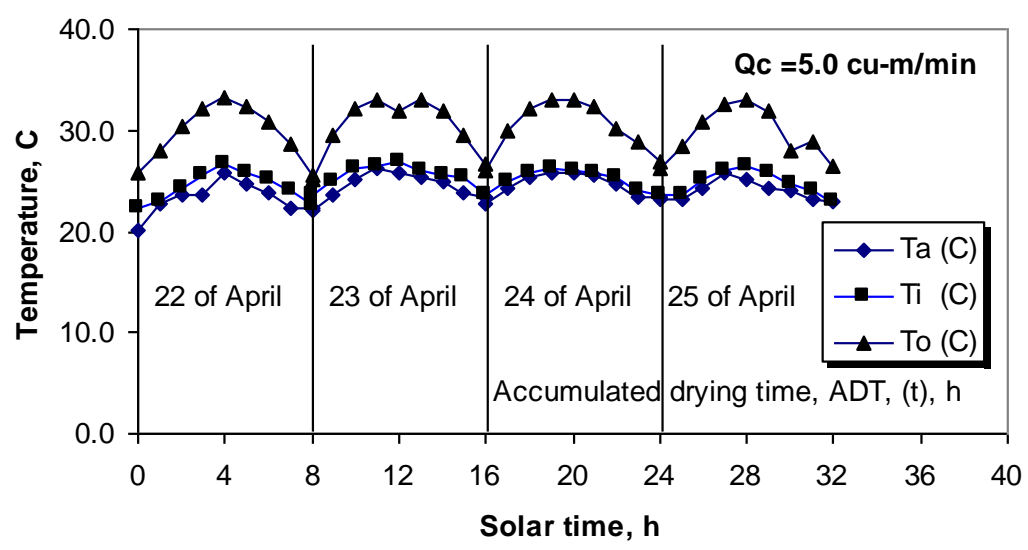

Fig. (7): Ambient air temperature (Ta), ${ }^{\circ} \mathrm{C}$, inlet solar collector air temperature (Ti), ${ }^{\circ} \mathrm{C}$ and outlet solar collector air temperature (To), ${ }^{\circ} \mathrm{C}$, versus accumulated drying time $(\mathrm{t}), \mathrm{Hr}$ and solar time with active solar drying system through a solar air collector airflow rate $\mathrm{Qc}=5.0 \mathrm{cu}-\mathrm{m} / \mathrm{min}$.

\section{CONCLUSION}

A- Natural sun drying system of marigold petals

1- The initial moisture content (IMC) was $663.36 \%$, dry basis, db and the equilibrium moisture content (EMC), db was $11.98 \%$ with an average relative humidity of ambient air $(\mathrm{RH}), 65.0 \%$.

2- The average drying rate (TDR), was $0.29 \% \mathrm{db} / \mathrm{min}$

3- The total drying time to ensure three values of equilibrium moisture content was $39 \mathrm{~h}$ and equilibrium moisture content time (EMCT) was $37 \mathrm{~h}$.

4- Finally, the natural sun drying system had the worst drying results because of both the lower ambient air temperature and lower average drying rate of marigold petals.

B- The passive solar-drying system of marigold petals

In the passive solar drying system, four treatments were run out, the first one (tunnel 1); the tunnel's door was opened and the natural air was passed through the samples within the bottom and upper air tunnel openings. The second treatment (tunnel 2); it has a natural convection, but tunnel's door was closed to accumulate maximum solar energy, and a black body was put below the samples to increase the required heat for 
drying marigold petals. In the third treatment (tunnel 3), the black body was put below the plastic sheet. In the fourth treatment (tunnel 4), tunnel's door was closed. The significant results were:

1- The initial moisture contents ranged between $545.16 \% \mathrm{db}$ and $663.36 \% \mathrm{db}$ while the equilibrium moisture content ranged between $9.69 \% \mathrm{db}$ and $10.77 \% \mathrm{db}$.

2- The maximum average relative humidity of ambient air (RHav) was $64.7 \%$ at tunnel 2 and the minimum average relative humidity of ambient air (RHav) was $52.9 \%$ at tunnel 1.

3- The lowest average tunnel temperature $\left(\mathrm{Tt}_{\mathrm{av}}\right)$ was $32{ }^{\circ} \mathrm{C}$ for tunnel 1 because tunnel's door was opened that leaded up to a minimum average drying rate (ADR) which had a value of $0.38 \% \mathrm{db} / \mathrm{min}$.

4- The maximum total accumulated drying time (TADT) had a value of $31 \mathrm{Hr}$ for tunnel 1.

5- The highest average temperature $\mathrm{Tt}_{\mathrm{av}}$ in tunnel 4 was $41.2^{\circ} \mathrm{C}$ due to the closed tunnel's door which worked as accumulated the solar radiation. Consequently, it maximized the average drying rate (ADR) which had a value of $0.64 \% \mathrm{db} / \mathrm{min}$. Also, it minimized the total accumulated drying time (TADT) which had a value of $16 \mathrm{~h}$.

6- Tunnel 2 and tunnel 3 results had approximately the same drying characteristics.

7- Average ambient air temperature $\left(\mathrm{Ta}_{\mathrm{av}}\right)$ ranged between $22.6^{\circ} \mathrm{C}$ and $26.1^{\circ} \mathrm{C}$.

C- The active solar-drying system of marigold petals

An air solar collector was used to heat a forced air to dry marigold petals. Three levels of airflow rate $(\mathrm{Qc})$ passed through the used solar collector were 2.7, 3.6 and $5.0 \mathrm{cu}-\mathrm{m} / \mathrm{min}$. The designed solar heated air values passed through the four dishes of drying bed $(\mathrm{Qb})$ were 0.675 , 0.900 and $1.250 \mathrm{cu}-\mathrm{m} / \mathrm{min}$. The summary of results were:

1- The initial moisture content (IMC), \% ranged between $545.16 \% \mathrm{db}$ and $663.36 \% \mathrm{db}$ while the equilibrium moisture content (EMC), \% varied from $8.36 \%$, db to $10.68 \%$, db.

2- The average relative humidity of ambient air was limited between $55.4 \%$ and $63.9 \%$. 
3- The maximum average ambient air temperature was $25.0^{\circ} \mathrm{C}$ and the minimum average ambient air temperature was $24.1{ }^{\circ} \mathrm{C}$ during the time of running experiments.

\section{REFERENCES}

Agricultural Statistics (1984). The Ministry of Agriculture and land Reclamation, Economic Affairs Sector.

Agricultural Statistics (1994). The Ministry of Agriculture and land Reclamation, Economic Affairs Sector.

Akradalieve, A. (1980). Experimental study of influence of heat transport media, temperature and velocity on drying intensity in chamber type solar dryer. Geliotechnicko, 16 (4): 78-79 (C.F Othman 1996).

Bezner, K., F. Biller, R. kellermann and H. Bohrmann (1987). Flowable dried aromatic plant product and process for making the same. Bibliographic citation: Manilla, philippins Patents Office. (C.F computer sheet).

Bogers, R.J., L.E. Craker and D. Lange (2006) Medicinal and Aromatic Plants, 237-252. 2006 Springer. Printed in the Netherlands.

Buser, M.D.; M.L. Stone; G.H. Bruswitz; N.O. Moness and D.P. Whitelock. (1999). Thin-layer drying of marigold flowers and flower components for petals removal. Transactions of the ASAE. 42 (5):1367-1373

Heber W. Youngken. (2003). Textbook of Pharmacognosy, $6^{\text {th }}$ ed. (16).

Megahed, M. Y. (1980). Studies on production, characteristics and utilization of Dill essential oils. M. Sc. Th, Fac. Ag., Cairo, Egypt.

Mohamed, L. Ait, M. Kouhila, A. Jamali, S. Lahsasni, N. Kechaou and M. Mahrouz (2005). Single layer solar drying behaviour ofCitrus aurantium leaves under forced convection. Energy Conversion and Management, Volume 46, Issues 9-10, June 2005, Pages 14731483.

Muller, J. (1992). Prediction of drying rate for solar drying. An ASAE Meeting Presentation Paper No. 926040.

Shokr, A. Z. (1984). Anew thin-layer drying equation for rough rice. Misr J. AG. Eng. 3. (1): 3-12. 


\section{الملخص العربيى}

تأثير نظام التجفيف الطبيعى الشمسي و نظام التجفيف بالطاقة الثمسية الخاملة

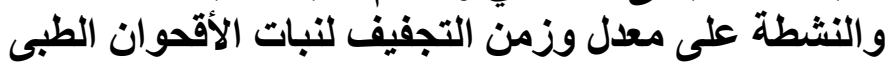

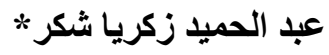

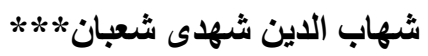

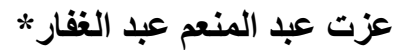

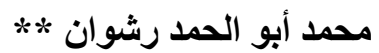

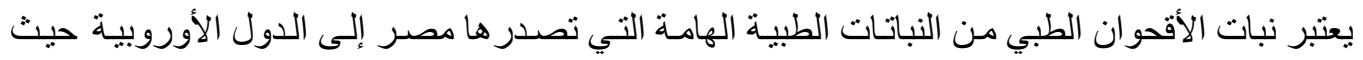

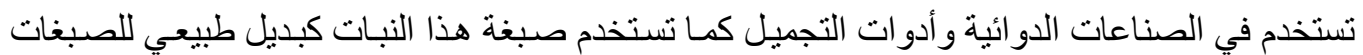

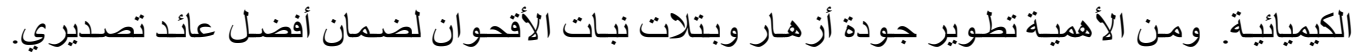

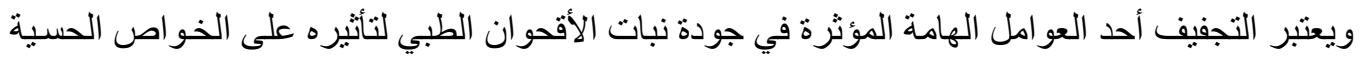

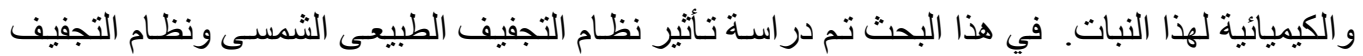
بالطاقة الثمسية الخاملة و النشطة على معدل وزمن التجفيف لبتلات نبات الأقحوان وكانت النتائج كما

\section{أولا: نظام التجفيف الطبيعى الثمسى لبتلات نبات الأقحوان}

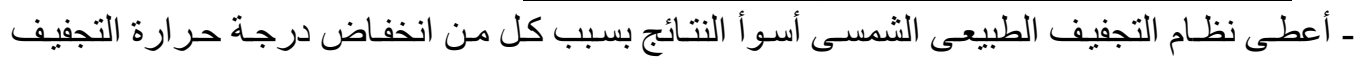

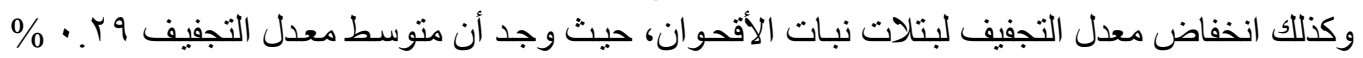

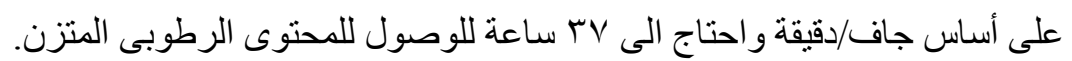

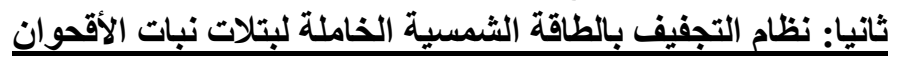

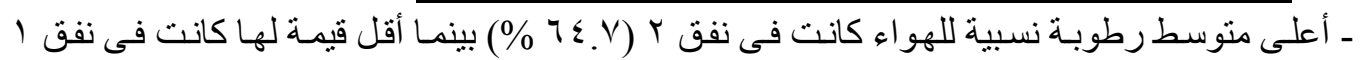
. (\%०r.9)

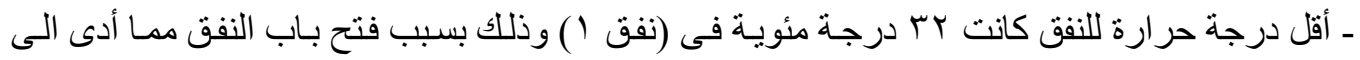

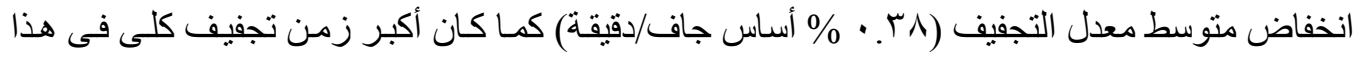

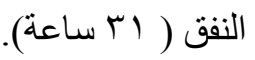

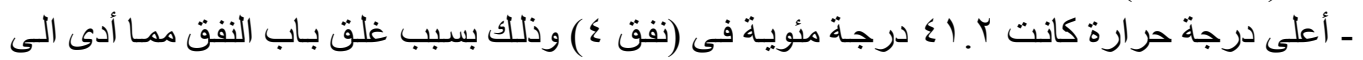

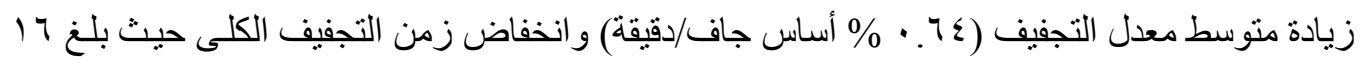
ساعة فقط.

\section{ثالثا: نظام التجفيف بالطاقة الثمسية النشطة لبتلات نبات الأقحوان}

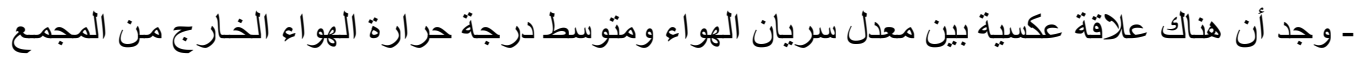

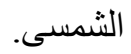

ـ ـ أعلى منوسط معدل تجفيف للبتلات لم ينأثر بمعدل سريان الهو اءو وذللك لاستخدام التجفيف فى طبقة رقيقة.

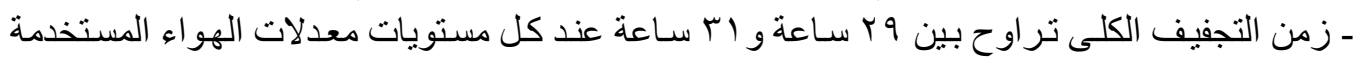

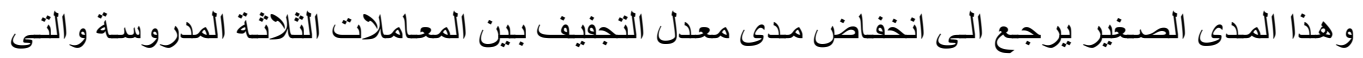

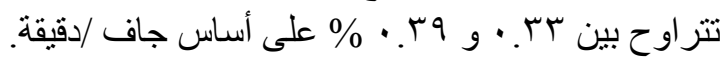

* أستاذ بقسم الهندسة الزراعية والنظم الحيوية ـ كلية الزراعة - جامعة الإسكندرية.

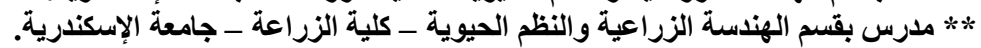
** * مهندس زراعى - ماجستير الهندسة الزراعية النية ـ كلية الزراعة - جامعة الإسكندرية. 